\title{
FINANCIAL INTELLIGENCE AND ITS BARRIERS IN THE INVESTIGATION PROCESS OF COUNTERING THE FINANCING OF TERRORISM IN PAKISTAN
}

\author{
Ayaz Khan \\ Director Research and Analysis, \\ Counter Terrorism Department Police Khyber Pakhtunkhwa, Pakistan \\ expert.aml.cft@gmail.com \\ Jamil Ahmad \\ Professor, Institute of Peace and Conflict Studies, \\ University of Peshawar, Pakistan \\ jamilchitrali@uop.edu.pk \\ Jan Alam \\ Lecturer, Department of Social Work \& Sociology, \\ Kohat University of Science \& Technology-KUST \\ Kohat, Pakistan \\ janalam@kust.edu.pk
}

\begin{abstract}
The study was performed with the principal focus on exploring gaps in the investigation process of countering the financing of terrorism in Pakistan. The study used a qualitative method to explore the barriers of investigation in financing terrorism. A set of 25 participants was selected purposively and interviewed through an in-depth, semi-structured interview guide. The thematic analysis technique was utilized for the findings and unearthing the gaps/reasons for failure in an investigation of countering the financing of terrorism in Pakistan. There were gaps explored in terms of securing prosecutable evidence in the investigation processes of money laundering. The major elements behind terrorist financing are found to be money transferred through Hawala, income generation through Chanda/donations, less or no access to traditional funding, the absence of effective monitoring on the national level, and poor access to the digital economy. The researchers recommend that such elements need to be controlled and be brought in line with that of FATF's to improve the image of Pakistan.
\end{abstract}

Keywords: Anti-money laundering; Financial Intelligence; barriers; qualitative research

\section{INTRODUCTION}

Countering the financing of terrorist organizations has always been important and a challenge for every state or organization. In the modern age, terrorists are funded through various ways and means, yet many of these are still unexplored (Yusuf \& Levy, 2019; Lowe, 2006). In recent ages, an important organization is being established, called combating the Financing of Terrorism (CFT) to overcome and monitor the financial growth and transactions of terrorist organizations across the globe. The CFT involves a variety of methods based on certain laws, rules, and regulations that are desired to control the funding and financial activities of all those organizations that are declared terrorists by that government. The CFT monitor terrorists funding sources, such as bank transactions, business, donations and, illegal mean of the economy like drug dealing (Yusuf \& Levy, 2019; FATF, 2007; Kohlmann, 2006).

Similarly, one of the major funding source is money laundering for terrorist financing, both involve the need to disguise the illicit sources of funds. Terrorist financing has certain similarities with traditional money laundering, namely the use of the three steps: place, layer, and integrating the funds in the international financial system. In the case of money laundering, the steps taken to hide the origins of the money will be the primary offenses, but the illegal actions taken to raise the money in the first place would constitute predicate offenses. A predicate offense 
for money laundering is the underlying criminal activity that generates proceeds that result in the commission of the offense of money laundering (FATF, 2006).

In light of the above facts and findings, this study was designed to reach the depth of the sources of finance and the barriers to overcome these. The study was conducted under the following research questions;

Research Question: What are the major sources of terrorist funding and the barriers to overcome these sources?

Objectives: To explore the major sources of terrorist funding and the barriers to gain control over such sources.

\section{REVIEW OF LITERATURE}

Terrorists used various sources of funds for their operation and adaptation, controlling their financial sources is not a new challenge. These may range from conventional to modern, all require close monitoring and check to control their funding activities. Combating the financing of terrorism includes bank policies and principles used to comply with the international anti-money laundering laws. The primary principles involve the collection of clients' information, identification of their funds' generation, and reporting the doubtful transactions (FATF, 2019). It is also reported that CFT needs to closely monitor the illegal funds sources, such as drug supply, extortion, smuggling, and kidnapping. Whereas legal sources, for instance wealthy altruists, welfare organizations, and business deals (Yusuf \& Levy, 2019; FitzGerald, 2004). Hence, an unchecked or poorly monitored fundraising will lead to the accumulation of money for arms purchase, establishing terror cells, salaries, and advancement in the group's goals.

Pakistan Mutual Evaluation Report provides the domestic risk assessment performed in 2017 was ineffective for several reasons including the very little attention towards the analysis of all the ML and TF risks comprehensively. The sharp inability of FMU was in terms of ensuring the ready availability of that financial intelligence with the Counter-Terrorism Departments (CTD) operative in the provinces. The non-dissuasiveness and mal-proportionate sentencing in terms of actions against the natural person in money laundering cases established that the struggle made by enforcement apparatus was not in line with the risk of ML, prevalent across the country (APG, 2019).

Moreover, Pakistan Mutual Evaluation Report also provided that the majority of the financial institutions were found aware of their legal domain and responsibilities in place for CML/CTF. Pakistan Mutual Evaluation Report asserted that it was noticed in the process that all efforts remained centered upon the information, which was provided to a very limited segment of the society. Pakistan Mutual Evaluation Report provides that Pakistan had not worked out the risk of ML and TF in the context of all kinds of legal people (APG, 2019).

While the writers of the work of Malaysia to adopt the FATF guidelines, they argued that there were still legal and regulatory flaws in the AML/CFT scheme. The vulnerability of the formal and informal financial systems was illustrated, they concluded, by money laundering and terrorist financing. Stamp and Walker (2007) had described the multi-source approach and the technique in a substantive manner when assessing the link between criminal proceeds and the essence of the crime. In addition, the Joint Appraisal Process showed the Member State's contribution to the application of the FATF requirements and the remedial weaknesses in their programs. It also noticed some weaknesses on the level of the competence targeted by qualification programs, the realities of anti-money-laundering (AML) and cyber security are different environments, lack of regulatory measures on the topic of cryptocurrency, dissuasion, and the reality of researchers in AML who require experience in cyber security matters such as network surveys.

Tuba (2012) argued that Southern Africa is a member of the FATF, the Intergovernmental Agency responsible for the development and regulation of terrorism-financing is of international standard to fight money laundering. In criminalizing money laundering and applying preventive steps to deter money laundering to financial processes, a country is expected to comply with these standards and to penalize the launderers that had defined particular benefits, 
which needs attention. It was observed that the potential contribution of regulatory implementations to IT is less emphasized by the importance of IT investment in the company and the empiric of the IS region. This confusion could lead many actors in the international financial system to shut down the possibility of illegal financial fraud and to increase the exploitation of money launderers and terrorist financiers worldwide.

Similarly, in an investigation into the introduction of anti-h and anti-terrorist finance programs insides financial institutions, Othman and Doherty (2014), sought to fill IT holes. De Koker (2009), examines the nature extent of illegal harassment for financial goods categorized as involving a low risk of anti-h/fighting of terrorist funding in a country to examine the impact of streamlined due diligence procedures for such products. It discusses the use of international antimoney-laundering money and the fight against terrorist funding. The IMF has demonstrated a desire to conduct independent research on its operation, a willingness to raise fundamental questions on the goals and feasibility of AML/CFT regimes, and a determination to innovation in measurement methods, an opportunity to explain AML/CFT priorities and aims.

Likewise, Madzima (2009) also highlighted the dangers of money laundering and the funding of terrorism and offers an overview of AML and CFT regimes. It concludes that the realization of international norms will continue to be a problem in the absence of a risk-based solution to these problems. Ozaki (2019), discusses the use of emerging technical technologies to address problems, such as enforcement complexities of financial fraud, intensified regulatory oversight, and the rising cost of programs and databases that impact the anti-monetary money laundering and counter-terrorism financing strategy.

A better understanding of the current situation in the banking market was given and the main problems of modern risk management and the efficiency of this management approach are addressed, in particular, in the fight against the laundering of proceeds from crime and terrorist financing of banking operations. Banks are the center of money laundering and terrorism funding because the banks owe their customers the responsibility of secrecy. Failure to add the result marks to results and events misses an opportunity to measure the influence and effect of antimoney laundering policies. The new prospect is important to create strong coordination between the financial smart unit and reporting parties to optimize the eradication of money laundering cases.

Rusmin and Brown (2012) also established that inventories are subject to new legislative requirements and regulations in different countries regulating mobile money and review the regulatory approach adopted concerning the problem of money laundering and terrorist funding. Regulation and enforcement in the Chinese financial sectors of anti-money laundering are money laundering flaws and a 'rule-based and a risk-based AML strategy. The American Bankers Association (ABA) welcomed the Financial Crimes Compliance Network comments on the proposal to make transparent and improve consumer due diligence standards and to make them more compliant with the Financial Crimes Network proposal to ensure customer due diligence. The network establishes that the banking sector is willing to collaborate with FinCEN and the Financier, as was shown for decades, to assess if the right plan on the processing of low-profit ownership data is a feasible solution to government record-keeping can be adapted. The value of designated non-financial enterprises and occupations in combating money laundering and terrorist funding was widely recognized by policymakers and law enforcement agencies.

The explanation for the difficulties of raising the amount of money-laundering lawsuits and terrorist finance cases is stated in Nazri, et, al., (2019). The new opportunities are important to establish strong cooperation among the Financial Smart Unit and the reporting parties to optimize money laundering eradication. The practice efficacy of internationally-approved and widely agreed CTF criteria to preventive money flow for terrorist purposes, which is analyzed in the Gilmour et al. (2017), using the crime script. Present money laundering must also be discredited to expand the possibilities of and examination of money laundering. The impact on the money laundering of board characters in Iranian listed firms is investigated by Mohammadi and Naghshbandi (2020).

It discusses international evidence on the trafficking of illegal profits and ends with an assessment of the impact of these findings on organized crime and anti-money laundering efforts. Naheem (2015) contended that there is still a significant reaction in risk management techniques 
and the ties between the banks exposed to two reasons, the risk not understood, which they did not analyze and the new cases arose from victims of ML and terrorism. The imminent mission for this sector is to build and co-develop the network of 'knowledge practitioners' and 'Knowledge management' in the global area of AML is the first and most critical job.

Likewise, Miller et al. (2016), outlined that the use of the international trading system for the transfer of value and the darkening of the true origins of illegal wealth is trade-based laundering. The purpose of this paper is to discuss the size and details of the TBML problem. The purpose of this study is to investigate gaps in preventive mechanisms for combating money laundering and anti-terrorism finances by countries, in addition, it also identifies the deficiencies in legislation, acts, and preventive measures for combating cash laundering and terrorism financing. It is also helpful in providing a concrete understanding of and contribute to the theoretical development of the AML/CFT concept of AML and terrorist funding. Misapplication to outputs and activities of the result labels misses the opportunity to assess results as the impact and effect of anti-money laundering policies.

Similarly, Kanak (2016), also investigated the importance of the integrity of financial systems in combating money laundering and funding terrorism crimes. Chohan (2019), says that in 1989, as a result of an attempt to strengthen anti-money laundering and terrorist finance practices around the world, the Financial Action Task Force formed and presents the public with the critical context and critical views of the FATF.

Chohan (2019) reported that the potential benefits to criminal persons are important, but it neglected the factor in the spread of cryptocurrency as a tool for money laundering. They underline the insurance industry's position as the latest field and as a part of the capital market in consideration of cryptocurrency. Bitcoins are part of the financial operations related directly to the IT sector but had lately become the focus of legislative attention because of the difficulties they had caused. The key conclusions of this, Naheem (2017), is that banks are constitutionally more liable than historically for the identification and notification of suspect transactions. The focus on financial police in Canada is an opportunity to reflect on the formalization of the suspicion in general, outside police agencies and intelligence organizations. The names of such persons are included in the 4th schedule as prescribed by the Ministry of Interior and can be subjected to restrictions on travail, speech, and business administered by the local police under a surety bond. A 4th scheduler, if wants to move out of the jurisdiction of the concerned Police Station or his city residence, must inform the local police station. The $4^{\text {th }}$ schedulers are kept under surveillance by the police to mitigate the possibility of their involvement in any terrorist activity in the future. This provision implies that a person can be placed on the 4th schedule whether he is concerned with terrorism or sectarianism.

To overcome the transaction through money laundering, some states, such as Pakistan have developed a mechanism like "The Anti-Terrorism Act-1997", and the Anti- Money Laundering Act-2010, as the primary legislation that deals with the domestic regime of CTF. The deliberations below highlight the powers of law enforcement agencies to be utilized for terrorism financing and anti-money laundering investigations, which had to be balanced with due process rights as provided for in domestic legislation and enshrined in the Constitution of Pakistan.

The use of modern technology, such as computers and the internet also facilitates the terrorists to secretly operationalize their funding activities. They are skillful to take advantage of the innovations, such as cryptocurrency, i.e., Bitcoin. Many CFTs are unable to approach their fundraising through crypto-currencies. Likewise, some governments are also unable to take serious steps against those who support terrorist funding, making trouble for the international community (McGee, 2020).

\section{METHODOLOGY}

This qualitative study followed a qualitative method for the in-depth analysis of the barriers to combat terrorist financing. The participants of the study comprised of national stakeholders taken from federal and provincial agencies to get homogeneity of the participants and ensure comparable facts for the analysis. The participants comprised of the 25 representatives as recommended by (Oppong, 2013), five each from the Federal Investigation Agency (FIA), National Counter Terrorism Authority (NACTA), Federal Board of Revenue (FBR), Anti- 
Narcotics Force (ANF), and Counter-Terrorism Department (CTD).

Data collection was done through interviewing the participants as highlighted in the research population. However, in-depth open-ended interviews were conducted with the participants based on purposive sampling, ensuring representation of all stakeholders (Creswell, 2014). Keeping in view of the COVID-19 situation prevalent in the country, the majority of the respondents were approached through a medium that is comfortably available to the participants. Based on the comfortability of the participants, some interviews were also conducted online and through cellular contact.

The interview questions were based on critical reviewing of legal documents, court cases, judgments, evidence, and investigation. The interviews were conducted in Urdu, Pashto, and English languages. The primary data was collected through tape-recording and written format, after prior consent taken from every participant. The data was transcribed and analyzed by using the thematic analysis technique recommended by Stirling, (2001). The major elements behind terrorist financing explored through this study includes money transferred through Hawala, poor screening in Banking, offshore financial activities, less or no access to funding through drugs smuggling, absence of effective monitoring on the national level, and barriers due to the digitalization of the economy.

\section{RESULTS AND DISCUSSION}

The finding of the research reveals that there are two types of major sources of funding terrorist organizations. The first one is the oldest or traditional source, known as Chanda (in the local parlance)/charities and the second one is the modern source, which is banking and cryptocurrency. The researchers have found that CTD and FIA are trying hard to investigate the finding sources and stopping their financers and curb their activities. However, due to certain reasons/barriers that limit the capacity of the investigation officers to fully control their funding. Some of the major elements explored through this study are as follow;

\section{Funding through traditional sources}

The terrorist organizations mainly operate in rural areas where they motivate the people on the basis of religious motives, such as Sharia and Chanda in the name of Jihad/Holy war. They mainly collect Chanda on Friday after Friday prayers, where a large gathering can be seen in every mosque. Many people wholeheartedly pay them, accelerating their fund generation. The militant organizations collect a huge sum each year through Chanda, which doesn't appear on official record.

A participant Azeem Ud Din responded that;

"You know we are trying our level best to fully control the militants' sponsors, however, we could not do so, because they mostly generate their funds in rural areas where they are paid direct cash or sometimes they are given arms, clothes, and grain. All these have no record, thus creating a hurdle in the investigation process".

Another participant Bilal Khan also added that;

"I believe that the funds collected through Chanda are one of the prime sources, terrorist organizations used for their funds' generation. It is one of the safer/hidden sources especially from the investigation officers".

Secondly, most terrorist organizations generate their funds from drug smuggling and transportations. It is found that the production of drugs such as opium and cannabis were used by militants' groups in Pakistan for their fund generation. They also collected Bhatta/extortion from the drug dealers especially in tribal areas such as former FATA.

A participant Fazal Khan added that;

"I would say that drugs production had vital importance in funding terrorists. The terrorist had received much of the funds from drugs production in FATA. The investigation officers have no access due to legal position of former FATA and no record of such funds, which is a major barrier of investigation".

Participant Kaleem Ullah reported that;

"I had observed that terrorists have not only generated funds through drug 
transport but also collected Bhatta from drug dealers, traders, and local merchants. The residents of the areas did not report to the government as they were harshly sentenced, even beheaded".

The third source of cash transfer is Hawala or Hundi, which is also an illegal transfer of cash from one place to another. A large number of hidden Hundis are operating in Pakistan, many of them are already banned by FIA. As these are also beyond the reach of investigation officers and can provide a safer transfer of cash, the terrorists also used these for transfer of money from one place to another.

An interviewee namely Sajid Khan replied that;

"I worked against the operations of Hundis for a long time. I found that many of them are licensed and are doing legal operations. However, not all are legal and a large number of these are illegally operating and transferring money from one place to another, also used by terrorists for their money transfers. These cannot be fully controlled due to no official record".

\section{Contemporary or Modern Sources of Transaction}

In modern societies, banking and online cash transfer are one of the biggest sources of money transaction. They all are operating under a legal procedure designed by the state and are bound to share any of the information required by the investigation agencies against a person or group. In terms of terrorist funding, bank transactions are not commonly used, as these are closely monitored by the security agencies and have easier access to them.

A participant Shahid Khan responded that;

"We are closely monitoring the money transfer through bank, however, the militant organizations are now aware of the fact, thus they avoid keeping their money in banks or transferring through a bank. The banks are also using an advanced system (Biometric) to ensure the account data".

The second participant Javed Khan added that;

"Before any amendment and mandating the CTDs used to seek courts' permission for grant of such financial intelligence required in TF investigations. However, the variation of its utility in TF investigations is linearly related to the nature of the offense and charges leveled in TF cases".

The application and the use of cryptocurrency are also considered as one of the safer means of transaction. They are not easily accessed and can privately benefit a person organization. However, it is believed that very few terrorist organizations can benefit from it because of their lack of knowledge to use modern cryptocurrency; they mainly rely on traditional systems. A participant Arif Gul added that;

"Of course, I believe that terrorists can get enough benefits from cryptocurrency, but I did not find any such case so far. We cannot deny such transaction and must also keep a check on it"

Another Participant namely Asad Khan expressed that;

"We need access to online transactions especially cryptocurrency for successful operation and investigation to strengthen the investigation and financial intelligence. It is also necessary to make legislative reforms for both mobile money and bitcoin etc,".

\section{CONCLUSION}

This study used an inductive approach to explore various facts about the barriers of terrorist financing and its investigation. It is found that militants are gathering money through different sources; the two basic sources among these are traditional and modern. Financial intelligence is very important to control the funding activities of militants; however, it is subject to many difficulties in Pakistan. The major barriers can be both traditional such as Chanda (i.e. donations) and Hundi, and modern transactions such as cryptocurrency.

The study findings are important in terms of adding a piece of new knowledge to control the sources of terrorist funding and enable the investigation officers to better cope with the barriers, they face during the financial intelligence process. This study also provides a new 
pathway to policymakers, government officials, and future scholars to explore/study financial intelligence from new dimensions.

\section{REFERENCES}

Asia Pacific Group, (APG, 2019). Anti-money laundering and counter-terrorist financing measures in Pakistan, Third Round Mutual Evaluation Report, APG, Sydney.

Chohan, U. W. (2019). The FATF in the Global Financial Architecture: Challenges and Implications. CASS working papers on economics \& national affairs. Retrieved from; https://papers.ssrn.com/sol3/papers.cfm?abstract_id=3362167. Accessed; June 13, 2020.

Creswell, W. J. (2014). Research design; qualitative, quantitative and mixed methods approaches. Sage publication.

De Koker, L. (2009). The money laundering risk posed by low risk financial products in South Africa. Journal of Money Laundering Control, 12(4), 323-339.

FATF (2006). Trade-Based Money Laundering: Typologies Report, FATF, Paris. Retrieved from; www.fatf-gafi.org. Accessed; July 24, 2020.

FATF (2007). Guidance on the Risk-Based Approach to Combating Money Laundering and Terrorist Financing: High-Level Principles and Procedures, FATF, Paris. Retrieved from; www.fatf-gafi.org. Accessed; March 10, 2020.

FitzGerald, V. (2004). Global financial information, compliance incentives and terrorist funding. European Journal of Political Economy, 20(2), 387-401.

Gilmour, N., Hicks, T., \& Dilloway, S. (2017). Examining the practical viability of internationally recognised standards in preventing the movement of money for the purposes of terrorism. Journal of Financial Crime, 24(2).

Kanak, A. M. A. (2016). Role of a financial intelligence unit in combating money-laundering and terrorist financing: an analysis on the functioning of Bangladesh financial intelligence unit. Journal of Humanities and Social Science, 21(7), 148-158.

Kohlmann, E. F. (2006). The role of Islamic charities in international terrorist recruitment and financing, DIIS Working Paper No. 2006/7, Danish Institute for International Studies, Copenhagen.

Levy, I., \& Yusuf, A. (2019). How Do Terrorist Organizations Make Money? Terrorist Funding and Innovation in the Case of al-Shabaab, Studies in Conflict \& Terrorism, [Online]. https://doi.org/10.1080/1057610X.2019.1628622

Lowe, P. (2006). Counterfeiting: links to organized crime and terrorist funding, Journal of Financial Crime, 13(2), 255-257.

Madzima, J. (2009). Money laundering and terrorism financing risks in Botswana. Institute for Security Studies Papers, 24 (1).

McGee, L. (2020). Security Council Preventing and Combating the Financing of Terrorism. Old Dominion University Model United Nations Society.

Miller, R. S., Rosen, L. W., \& Jackson, J. K. (2016). Trade-based money laundering: overview and policy issues. Congressional Research Service.

Mohammadi, S., \& Naghshbandi, N. (2020). Investigating the impact of board characteristics on money laundering. Journal of Money Laundering Control, 23(4).

Naheem, M. A. (2015). Money laundering using investment companies. Journal of Money Laundering Control, 18(4), 438-446.

Nazri, S, N., Zolkaflil, S., \& Omar, N. (2019). Mitigating financial leakages through effective money laundering investigation. Managerial Auditing Journal, 34(2), 190-207.

Oppong, H., S. (2103). The problem of sampling in qualitative research. Asian Journal of Management Sciences and Education, 2(2), 202-210.

Othman, A., \& Doherty, N. F. (2014, April). Uncovering Business Benefits From Regulatory Compliance Systems. In UKAIS (p. 24).

Ozaki, H. (2019). AML/CFT and new technologies: Challenges in Japan. Journal of Financial Compliance, 2(4), 342-361.

Rusmin, R., \& Brown, A., M. (2012). Regulatory context. Journal of Money Laundering Control, l(1). 
Stamp, J., \& Walker, J. (2007). Money laundering in and through Australia, 2004. Trends \& Issues in Crime \& Criminal Justice, (342). Retrieved from; https://www.aic.gov.au/publications/tandi/tandi342, Accessed; 15 Feb, 2020.

Stirling, A. J. (2001). Thematic networks: an analysis tool for qualitative research. Qualitative research, 1(3), 385-405

Tuba, D. (2012). Prosecuting money laundering the FATF way: an analysis of gaps and challenges in South African legislation from a comparative perspective. ActaCriminologica: African Journal of Criminology \& Victimology, (2), 103-122. 